\title{
A MEANS OF COMPARING MILITARY BUDGETING PROCESSES IN SOUTH EAST EUROPE
}

\author{
Todor TAGAREV
}

\section{Introduction}

Throughout the last decade of the Twentieth century, the countries in South Eastern Europe (SEE) suffered from war and conflict, enduring at the same time the hardships of the transition to market economies. With the end of hot conflicts, democratic transformations are leading to fundamental restructuring of armed forces, changing the role of the military in their national political systems. Currently, all SEE countries are in the process of establishing effective democratic control over the armed forces, motivated to introduce the practices of transparency and accountability throughout government, the area of defence included.

Military budgeting is one very important component of democratic governance of defence. Traditionally, military budgets have been considered one especially sensitive area out of societal reach. As a result, although parliaments have the responsibility of deciding on and overseeing the execution of military budgets, very few people is SEE can credibly discuss the issue of "How much is enough?" The number of people in SEE with the grasp of the complexity of the military budgeting process is still quite limited. Traditional practices and non-transparent group interests too often prevail on the issues of the size and the structure of military budgets. Moreover, parliaments vote on military budgets, but the elective representatives of the people rarely understand the meaning of their decisions with respect to national security and defence policies.

Therefore, one of the very early initiatives within the Stability Pact for South Eastern Europe aimed to promote the transparency of military budgeting; transparency being understood both in terms of availability of information on budgets and budget execution and in terms of open, policy-oriented decision making process. Understanding that military budgeting is at the heart of the democratic control of the armed forces and comprehensive regional stability, the Budget Transparency 
Initiative (BTI) of the Stability Pact aims to promote domestic and international transparency of defence budgets and the defence budgeting process throughout South Eastern Europe and to encourage good practices in defence decision making (policy making, planning, programming and budgeting), with particular reference to accountability.

In line with the BTI objectives, this paper presents a methodology for comparative assessment of military budgeting processes. Once implemented, this methodology will allow the participants in the SP Budget Transparency Initiative and other beneficiaries to identify:

1. Areas where SEE countries have achieved important progress in implementing effective budgeting procedures and their experience may be useful for other BTI countries and beneficiaries through encouragement of the dissemination of good local practice, and

2. Areas where all SEE countries lack necessary expertise and/or experience and the region as a whole would need focused outside support to improve military budgeting practices.

\section{Approach}

In pursuit of the BTI objectives, this paper provides a description of an idealisednot necessarily existing - budgeting process to serve as a benchmark. The underlying approach is to assess military budgeting processes in individual SEE countries against this benchmark.

Annex A provides a questionnaire to assess budgeting processes against a hierarchy of criteria structured in five major groups: (1) policy orientation of the budgeting process; (2) effectiveness of budget planning; (3) budget execution and oversight; (4) transparency; and (5) integrity. Annex A includes also sets of possible answers to the questions, 'scaled' to allow comparison of SEE military budgeting provisions and practices to the benchmark.

The final section of the paper provides guidance on how to process respective answers to the questionnaire in order to accomplish stated objectives.

\section{Assumptions}

\section{Readiness for implementation}

The major assumption is that, ready to adhere to the Vienna understanding on the purpose of the BTI in South Eastern Europe, the SEE countries are willing to: 
- Implement practices that would facilitate good governance in the area of defence;

- Promote democratic accountability of the military and, generally, of the executive branch; and

- Share information to increase confidence in the region.

\section{Application domain}

The expectation is that the BTI team - the Academic Working Group and the Group of Experts, supported by the Centre of Excellence in Sofia-will apply the proposed methodology to assess military budgeting processes in SEE countries. To this purpose, the questionnaire accounts for a number of specifics of the SEE countries undergoing substantial defence reforms, lacking market experience, demonstrated for example in the lack of experience in competitive tendering, and possessing rather limited experience in military budgeting according to the principles of democratic governance.

The level of detail of the methodology is commensurate with the stated purpose and the current stage of democratic developments in SEE countries. More focused analysis would be required when the BTI team identifies one or more areas of possible improvement in military budgeting in South East European countries.

The methodology is intended for assessment of the current status of military budgeting in SEE. Additionally, its implementation may provide indications for the adequacy of planned improvements in military budgeting systems and practices and may assist SEE decision makers in assigning priorities to envisioned procedural, organisational and technological innovations related to military budgeting.

\section{Scope of 'budgeting'}

For the purposes of this paper, the term 'budgeting' comprehensively includes the military budget as a document, the process of planning the military budget (ideally, to reflect accurately a particular defence policy), the process of budget execution and accounting, and the system of audits, reports and legislative approval of budget reports.

\section{Characteristics of the benchmark}

Military budgeting processes in South East European countries shall be compared against an idealised system serving as a benchmark. Such a system does not necessarily exist. The budgeting system described in this section may be considered 'best' in 'good governance' terms of effectiveness, transparency and accountability 
and does not take into account sometimes legitimate concerns of sensitivity of information, secrecy, and limitation on the access to information.

The benchmark is described in five major categories of criteria assessing respectively: (1) Goal orientation of the budgeting process; (2) Scope and effectiveness of the budget planning process; (3) Budget execution and effective oversight; (4) Transparency of military budgeting and budgets; and (5) Assurance of integrity of military budgeting.

\section{Military budgeting as an integral component of the security and defence policy}

\section{I a. Objectives, vision, strategy}

Military budgeting is a process well incorporated in the defence planning framework, guaranteeing the implementation of a clearly stated defence policy in mid- and longterm. The country has clearly stated the objectives of its security and defence policies in a small number of legislative acts with apparent interrelationship among them. There is a comprehensive strategy to achieve the objectives of the security and defence policy, i.e., to join an alliance. This strategy-elaborated in a legislative act - is broadly assessed as realistic. The country has a vision of its force structure ten or more years in the future. The vision is feasible and sufficiently elaborated to guide $\mathrm{R} \& \mathrm{D}$, technology development and acquisition policies. Its implementation is supported by a roughly costed long-term force development plan. The vision and the long-term plan are approved either by the Government or by the legislature.

\section{I b. Programmatic approach}

The country has an established process for development of a mid-term plan, or defence programme, ${ }^{1}$ designed to accomplish the objectives of the stated defence policy. The defence programme and its components are clearly designed to meet policy objectives. It incorporates diverse requirements, e.g., on national defence and allied planning. The defence programme further includes programmes and projects considered of highest priority in terms of policy objectives. In a comprehensive manner it covers all defence activities and costs, including personnel, operations and maintenance $(\mathrm{O} \& \mathrm{M})$, procurement, utilisation, education and training, research and technology development, etc.

The defence programme is constrained by anticipated resources. It further constrains any other defence resource requirements posed, for example, by acquisition programmes or operational plans. It contains alternative options to reflect thoroughly described contingencies. The defence programme effectively incorporates performance indicators. The level of detail for the first planning year ${ }^{2}$ of the defence programme is sufficient to allow for its accurate transformation into budget plan. 


\section{I c. Defence and force planning risks}

There is a clear understanding of the risk level associated with the budgeted force structure and defence posture both in short- and mid-term. The country has a methodology to assess risks associated with defence and force planning, and this methodology is adequate to the country's needs. It has established procedures to develop scenarios for force implementation, to assess probability of occurrence of each scenario under clearly stated assumptions, to simulate performance of planned forces, to analyse simulation results and deduct risk. Furthermore, the assessment of risk is supported by relevant tools, while the experts involved have the necessary knowledge and experience. Finally, risk assessment is fully and effectively incorporated within the defence and force planning cycle.

\section{I d. Effective incorporation of military budgeting}

The budgeting procedure is clearly oriented to reflect precisely policy objectives and programme decisions. It allows for efficient and effective translation of policy and programme decisions into budgets.

\section{Budget planning}

\section{II a. Military budget planning}

Roles and responsibilities within the executive branch and among the braches of power in regard to military budgeting are very clear. That applies to the distribution of roles and responsibilities among the executive branch, the legislature, and the Head of State (the Supreme Commander); among the senior military authorities, the civilian MOD $^{3}$ officials and the Ministry of Finance; the roles and responsibilities of the public sector, commercial organisations and lobbying groups, in particular the relationships between the executives and commercial organisations owned by the MOD or other governmental agencies.

\section{II b. Flexibility}

Roles and responsibilities for key aspects of military budgeting are defined through comprehensive legislation, regulations, and instructions, covered by a budget system law. A degree of flexibility is available to the executives in spending public funds. Programmes and, respectively, budget can be changed out of the regular planning cycle. However, the discretionary powers of the executives are clearly described in legal acts. Contingency or reserve provisions of the budget law specify clear and stringent conditions for the use of funds. Executive reports on spending contingency funds are independently audited.

\section{II c. Military budgets}

In a comprehensive manner, the military budget covers all financing (subsidies and 'revenues'/'incomes') and spending. Comprehensively, with clearly defined sources 
and elaborated purpose, the military budget accounts for the subsidy from the state budget to the Ministry of Defence; subsidies from the state budget to other organisations performing defence and defence-related activities, i.e., maintenance of wartime reserves; funding from other national programs, i.e., for preparation for NATO membership; funding through international and bi-lateral programmes (with clear regulations for using reimbursed funds); revenues from sales of excess equipment, infrastructure, etc.; revenues from the profits of commercial organisations and organisations, providing goods and services to outside organisations, when the MOD owns or has a share in these organisations.

The country has the capacity-methodology, adequate knowledge and trained people - to estimate accurately all future defence expenditures, including the expenditures according to the UN Instrument for Standardised Reporting of Military Expenditures (Annex B), taxes, social and medical insurance costs, retirement costs and the costs for social adaptation of prematurely released military personnel, expenditures on utilisation of weapon systems, equipment and infrastructure, costs to cover previous contracts and loan servicing costs, as well as any contingent liabilities.

All revenues and expenditures are classified in a way that is compatible to the international standards, i.e., GFS ${ }^{4}$ and the UN instrument. Budget information is presented in a way that facilitates policy analysis and promotes accountability. The military budget is represented in the form of appropriations, giving considerable detail. It provides detailed distribution among defence organisations, as well as among defence programmes. In the latter case, the budget clearly presents the resources allotted to training, maintenance, procurement, research and development (R\&D), etc., for each programme and its elements.

\section{Budget execution and oversight}

\section{III a. Budget execution}

The country has a comprehensive accounting system that provides a reliable basis for assessing payment arrears. The accounting system is capable of generating data on all stages of the 'incomes' and payments along budget appropriations, as well as along organisations and programmes.

Personnel, operations and maintenance, procurement and $R \& D$ regulations are standardised and accessible to all interested parties. There are clear criteria for discretion on employment and payment, allowing for competitive recruitment. The regulations for open tendering for procurement, $R \& D$ and other contracting services are clear and comprehensive and the personnel involved in their implementation is adequately qualified. All these regulations are fully observed in practice. 


\section{III b. Auditing}

In the defence establishment and/or in the executive branch there is a strong capacity for internal audit. Internal audit procedures are clear and subject to effective process review by external auditors. There is a strong audit capacity both in terms of financial compliance and effectiveness of performance ('value-for-money' audits). Additionally, there is a strong capacity for independent audits, i.e., through a National Audit Office working for the legislature. Independent audit requirements and procedures are clearly established in law. There is a strong independent capacity for audits in terms of financial compliance and identification of fraud/mismanagement cases, as well as for 'value-for-money' audits. Independent think-tanks (universities, academic institutes and other non-governmental organisations) complement 'valuefor-money' audits in particular areas of interest, i.e., force modernisation programmes. Non-governmental organisations have a notable capacity and track record of successful performance reports. Their reports have had noticeable impact on decision makers and societal attitudes.

\section{III c. Reporting}

The government presents regular fiscal reports to the legislature and the public. A mid-year report on budget developments is presented to the legislature. More frequent - quarterly and monthly-reports are also published. Final accounts are presented to the legislature within six months of the end of the fiscal year. They are accompanied by comprehensive and in-depth analysis of performance relative to the major defence programmes. ${ }^{5}$

\section{Transparency of military budgeting}

\section{IV a. Transparent decision making}

All aspects of military budgeting (planning, execution and assessment of implementation) are transparent to decision makers and the public. All participants in the budgeting process - civilian and military planners, ministers of defence and finance, governmental councils, legislature and its committees, head of state, audit office, lobbying groups, non-governmental profit and non-for-profit organisations, media and society at large - exercise their influence according to clear rules and with full understanding of all aspects of the military budgeting process and adhere to the principles of democratic governance.

\section{IV b. Availability of information}

Publications of military budgets and related information-major security and defence policy documents, defence programmes, implementation and audit reports - are readily available to the public. The rules for disclosing military budgets and related information are also public. They are clearly defined in law and leave very little room 
for discretion by the executive agencies. The government and the respective agencies are legally obliged to publish information on military budgets in details, allowing rigorous analysis by an informed observer. The information is provided in printed version and on-line, both in the native language and in another commonly used language, i.e., in the English language. Furthermore, the executives, i.e. the Minister of Defence, are obliged by law to respond in writing to requests for information. If a portion of a related document is classified, ${ }^{6}$ that portion is deleted and the rest of the document is provided to the enquiring organisation or person.

Aggregate information on the budget and the actual or expected outturn of the two preceding fiscal years is readily available. Aggregate information on the budget forecasts for five or more years following the budget year is also available.

The country complies with international treaties and agreements that require disclosure of military budgeting information, i.e., UN and OSCE agreements and Stability Pact initiatives, regularly providing complete and accurate information on time.

\section{Assuring integrity}

Military budgeting is based on a rigorous and very reliable forecasting of the budget/fiscal constraints in a comprehensive and consistent quantitative macroeconomic framework. All underlying assumptions for budget planning, i.e., major fiscal risks, uncertain costs, specific expenditure commitments, etc., are clearly documented and properly accounted for. Furthermore, major underlying assumptions, such as macroeconomic forecasts, fiscal forecasts, etc., are assessed by independent experts.

All defence programmes are costed using a comprehensive and consistent set of cost factors that are clearly related to the findings of an independent national statistics agency. Integrity checks are supported by an information system. Programming and budgeting are systematically supported by an information system with tools for automated analysis and decision making support, allowing also collaborative work. The accounting basis is clearly indicated, with full statement indicating any changes in practices as well as current accounting policy.

Alternative programmes and budgets, corresponding to different assumptions, are clearly identified and documented. There is a clear written procedure to transition from one alternative to another, and transition points are also clearly documented. History of both plans and implementation results and assessments is readily available.

Fiscal reports are internally consistent and reconciled with relevant data from other sources. Effectively and in a timely way accounting reports are reconciled with 
budget appropriations and with bank accounts. Auditing of accounting reports is also timely and effective. There is rigorous reconciliation of fiscal and monetary data. A national statistics agency is provided with the institutional independence to verify the quality of budget data. International standards for budget data integrity and quality are fully adhered to.

\section{Matching SEE military budgeting processes to the benchmark}

The application of the methodology shall require (1) individual expert evaluation of the military budgeting process of each SEE country and (2) comparative analysis of the assessment results by a joint BTI team - the Academic Working Group, the Group of Experts, or a specially tailored team-with representatives of participating countries.

Theoretically, the accuracy of the assessment of the budgeting process of a particular country increases with the increase of the number of independent individual evaluations. However, given the limited number of military budgeting experts with sufficient language abilities from each country, it is desirable that three to five people independently fill in the questionnaire. Then the answers to a particular question may be averaged (according to the guidance below). However, if the answers to a question differ more than one degree in the respective scale, it is recommended that the BTI team clarifies the reasons for the difference and arbitrate on the agreement of an adequate answer.

Thus, the first step in the work of the joint analysis team is to process the assessments for each individual country and to clarify any existing discrepancies. The second step is to compare assessments among the SEE countries. Assessments for a particular criterion may be visualised using a simple scale, i.e., of uniform distribution between 0 and 1 , where ' 0 ' denotes negative answer, i.e., non-existence of a certain feature, and ' 1 ' denotes the characteristics of the idealised system. The questionnaire is structured so that the first among the answers would usually suggest a ' 0 ' and the last - ' 1 '.

In many of the cases simple visualisation may assist the joint analysis team in identifying opportunities for transfer of good local practice (Figure 1) or cases where SEE countries would need outside support to rapidly improve their military budgeting systems and practices (see for example Figure 2).

In the first case, countries $\mathrm{A}^{7}$ and $\mathrm{C}$ have solid achievements in terms of criterion $\mathrm{X}$. The transfer of their know-how and experience to countries B, D and E may contribute to the objectives of BTI. In the case presented on Figure 2, no country in SEE has the necessary knowledge and experience to implement adequately the requirements of the notional criterion Y. This may serve as an indication that the BTI 
team, and the Stability Pact, may consider focused outside support to improve the understanding, knowledge and experience in the respective component of the military budgeting process.

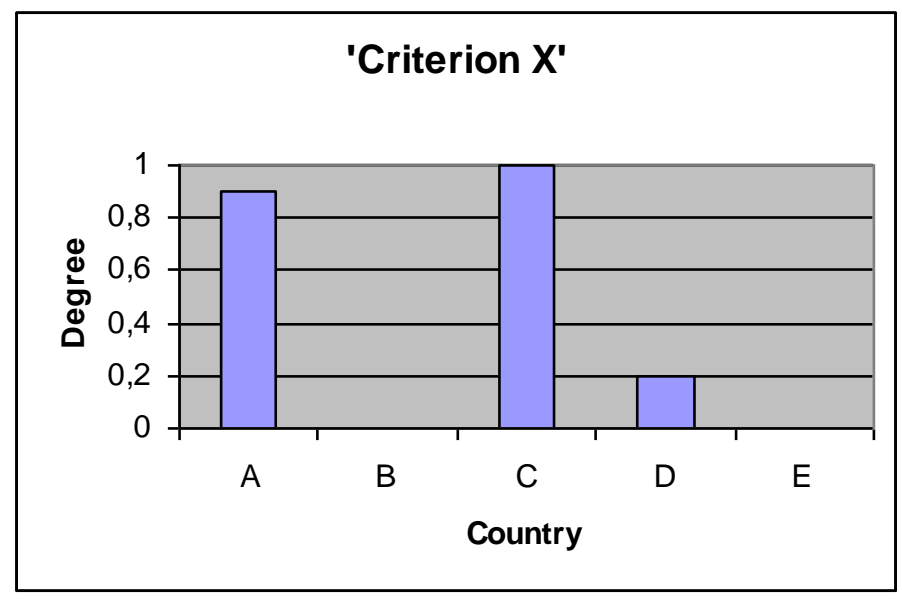

Figure 1: Opportunity for transfer of good local practice.

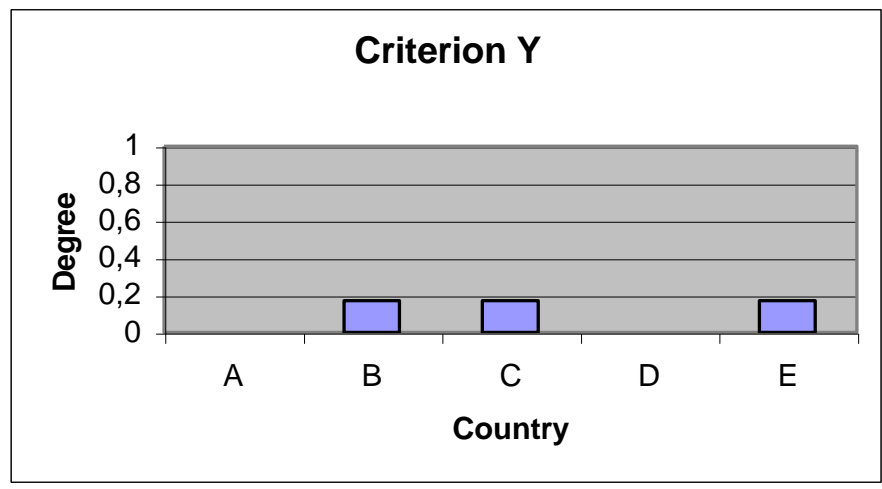

Figure 2: No SEE country has the necessary knowledge and experience to implement adequately the requirements of criterion Y. Outside support may be recommended.

A particular attention shall be given to aggregating the assessments in a group of criteria. When the relationship among the characteristics in the group is additive, the computation of a simple mean will suffice. If, however, the relationship is 
multiplicative, a simple averaging may mislead the analysis team. For example, excellent results according to one of the criteria in group 1.2.1. "Risk assessment" will not compensate for a negative answer-or ' 0 ' - to another question in the same group.

Though most of the characteristics of a military budgeting process lend themselves to such simple quantification that may be suitable for comparative purposes, others do not easily scale. Therefore, the focus of the analysis team shall be on qualitative interpretation of the individual assessments.

\section{Conclusion}

The countries in South Eastern Europe have already well-established co-operation in the area of military planning, budgeting and defence resource management in general. The expectation is that, once endorsed by the BTI Steering Group and applied effectively, the proposed methodology will be helpful in identifying the most pressing and promising areas for further co-operation.

Potentially, the methodology may be useful in other studies aiming to improve democratic governance, transparency and accountability in the public sector, in particular in the defence and the security sector.

ACKNOWLEDGEMENT. This paper was prepared in the framework of the Stability Pact for SEE Budget Transparency Initiative, supported by the UK Government. Its first version was improved as a result of presentations and discussions at the joint meeting of the Steering Committee and the Academic Working Group of the Stability Pact Budget Transparency Initiative in Vienna, 17-18 October 2002, and the international seminar on Advances in Defence Programming and Budgeting, Sofia, 78 November 2002.

DISCLAIMER. The experience of the author as Director of the Defence Planning Directorate in the Bulgarian Ministry of Defence, 1999-2001, was indispensable for the preparation of this paper. For over two years in that position the author benefited from the experience and the enthusiasm of a full time consultant from the UK Ministry of Defence. Nevertheless, the opinion and statements made here are those of the author and do not necessarily reflect the official position of the Bulgarian or the UK Government. 


\section{References and further reading}

\section{Selected BTI papers and reports}

1. Military Planning and Budgeting Transparency initiatives in the framework of the Stability Pact, Website of the Special Co-ordinator of the Stability Pact for South Eastern Europe $\rightarrow$ The Stability Pact's Working Tables $\rightarrow$ Working Table III $>$ Sub-table on Defence and Security Issues $\rightarrow$ Defence Economics <http://www.stabilitypact.org/stabilitypactcgi/catalog/cat_descr. cgi?subcat=1\&prod_id=45> (24 April 2003). Regular updates are also available at the BTI dedicated website, <http://bti-ce.mod.bg/> (24 April 2003).

2. Promotion of Transparency and Democratic Decision Making in the Formation of SEE States Military Budgets, Stability Pact for South Eastern Europe Seminar (Sofia, Bulgaria: 6-7 June 2000).

3. Transparency of Defence Budgeting, Paper endorsed by the Multinational Steering Group (Vienna, Austria: 15-16 March 2001), <http://www.stabilitypact.org/stabilitypactcgi/catalog/view_file.cgi?prod_id $=5118 \&$ prop_type $=$ en\&prop_unit=file_cont $>$ (21 September 2002).

4. Yearbook on South-East European Defence Spending, Stability Pact for South Eastern Europe (Sofia, Bulgaria: Budget Transparency Initiative, 2002), <http://www.stabilitypact.org/yearbook/index.htm> (27 March 2002).

\section{Official publications of international organisations}

\section{United Nations}

5. United Nations Instrument for Reporting of Military Expenditures, UN Transparency in Armaments Website <http://disarmament.un.org/cab/ milex.html> (27 September 2002).

6. United Nations Standardized Instrument for Reporting Military Expenditures, Reporting form in English, <http://www.un.org/Depts/dda/ docs/milexforms.xls> (27 September 2002).

7. Transparency in Military Matters Grows, UN Pres Release DC/2799 (31 July 2001), <http://www.un.org/News/Press/docs/2001/dc2799.doc.htm> (27 September 2002).

\section{Organization for Security and Co-operation in Europe}

8. Vienna Document 1999 of the Negotiations on Confidence-and SecurityBuilding Measures, FSC.JOUR/275 Istanbul, 16 November 1999, 
<http://www.osce.org/docs/english/1990-1999/csbms2/vienn99e.htm> March 2002).

9. A Framework for Arms Control, Organization for Security and Co-operation in Europe, FSC.DEC/8/96, <http://www.osce.org/docs/english/1990-1999/ summits/lisbo96e.htm> (24 March 2002).

10. Vienna Document 1994 of the Negotiations on Confidence- and SecurityBuilding Measures, FSC/2/95, Budapest, 28 November 1994, as supplemented by relevant decisions of the Forum for Security Co-operation, 17 February 1997. <http://www.osce.org/docs/english/1990-1999/csbms2/ vienn94e.htm> (23 March 2002).

11. Code of Conduct on Politico-Military Aspects of Security, in Budapest Document 1994: Towards a Genuine Partnership in a New Era, Conference for Security and Co-operation in Europe, 1994 Summit, Budapest, 5-6 December 1994, <http://www.osce.org/docs/english/1990-1999/summits/ buda94e.htm> (27 July 2002).

12. Global Exchange of Military Information, F165EW17, Budapest, 28 November 1994 <http://www.fas.org/nuke/control/osce/text/GLOBALXE.htm> (11 March 2002).

\section{International Monetary Fund}

13. IMF Fiscal Transparency Homepage, <http://www.imf.org/external/np/fad/ trans/> (30 July 2002).

14. Code of Good Practices on Fiscal Transparency, International Monetary Fund, <http://www.imf.org/external/np/fad/trans/code.htm> (24 April 2003).

15. Manual of Fiscal Transparency, International Monetary Fund, <http://www.imf.org/external/np/fad/trans/manual/index.htm> $\quad(30 \quad$ July 2002).

16. Questionnaire on Fiscal Transparency, International Monetary Fund, <http://www.imf.org/external/np/fad/trans/question/quest.htm> (30 July 2002).

\section{Articles, research reports and monographs}

17. Chris Donnelly, "Defence Transformation in the New Democracies: A Framework for Tackling the Problem," NATO Review 45, 1 (1997): 15-19, <http://www.nato.int/docu/review/1997/9701-4.htm> (14 July 2002).

18. David Greenwood, 'Transparency in Defence Budgets and Budgeting', in Transparency in Defence Policy, Military Budgeting and Procurement, ed. 
Todor Tagarev (Sofia: Geneva Centre for the Democratic Control of Armed Forces and George C. Marshall - Bulgaria, 2002), pp. 27-38.

19. Dobromir Totev and Bisserka Boudinova, "Information Support for Effective Resource Management," Information \& Security: An International Journal 6 (2001): 138-150, <http://www.isn.ethz.ch/onlinepubli/publihouse/ infosecurity/volume_6/b5/b5_index.htm> (12 July 2002).

20. Dylan Hendrickson and Nicole Ball, Off-Budget Military Expenditure and Revenue: Issues and Policy Perspectives for Donors, CSDG Occasional Paper \# 1 (London: Conflict, Security and Development Group, International Policy Institute, King's College, January 2002), <csdg.kcl.ac.uk/ Publications/assets/PDF\%20files/OP1_Off-Budget\%20Military\%20 Expenditure.pdf> (25 April 2003).

21. Michael Brzoska, "The Concept of Security Sector Reform," Brief 15: Security Sector Reform (Bonn, Germany: Bonn International Center for Conversion, June 2000): 6-13, <http://www.bicc.de/general/brief15/ brief15.pdf> (12 July 2002).

22. Nicole Ball, "Addressing Military Expenditures and Military Roles in Developing Countries: A Review of Members Approaches," Information DAC Task Force on Conflict, Peace and Development Co-operation, Organisation for Economic Co-operation, Development Co-operation Directorate (September 1998).

23. Todor Tagarev, ed., Transparency in Defence Policy, Military Budgeting and Procurement (Sofia: Geneva Centre for the Democratic Control of Armed Forces and George C. Marshall - Bulgaria, 2002). 
Annex A

\section{QUESTIONNAIRE on Military Budgeting Processes}

\section{Military budgeting is a process well incorporated in the defence and security planning framework}

1.1. The budgeting process guarantees implementation of clearly stated defence policy in mid- and long-term. That shall include the following items:

1.1.1. The country has clearly stated the objectives of its security policy

- No

- The objectives of the security policy are defined in expert document(s) of the security services and/or Defence Staff

- Definitions in document(s) of the Government/MOD or other governmental organisations

- Definitions in document(s), authorised by the legislature

- Clear and comprehensive statement in a legislative act (or in a small number of legislative acts with apparent interrelationship among the documents)

1.1.2. The country has clearly stated the objectives of its defence policy

- $\quad$ No

- The objectives of the defence policy are defined in expert document(s) of the Defence Staff and/or the security services

- Definitions in document(s) of the Government/MOD

- Definitions in document(s), authorised by the legislature

- Clear and comprehensive statement in a legislative act (or in a small number of legislative and governmental acts with apparent interrelationship among the documents)

1.1.3. There is an elaborated strategy to achieve the objectives of the security and defence policy, i.e., build an alliance, neutrality, etc.:

- $\quad$ No

- Some elements of a strategy are defined in expert document(s) of the 
Defence Staff and/or the security services

- Elements of a strategy are defined in document(s) of the Government/MOD

- There is a strategy, defined in legislative document(s)

- A comprehensive strategy, broadly assessed as realistic, is elaborated in a legislative act

1.1.4. The country has a vision of the future force structure, i.e., ten or more years into the future

- No

- Some elements of a vision are defined in expert document(s) of the Defence Staff

- Document of the MOD/the Defence Staff defines a vision that is feasible, i.e., generally assessed as realistic in terms of future force requirements and available resources

- The country has a feasible vision, i.e., sufficiently elaborated to guide $R \& D$, technology development and acquisition policies, that is approved by the Government and/or the legislature (please briefly describe)

- The country has a roughly costed long-term plan for the development of the envisioned force structure, that is approved by the Government and/or the legislature (please briefly describe)

1.1.5. The country has an established process for development of mid-term plan, or defence programme, designed to accomplish the objectives of the stated defence policy. The defence programme can be characterised in the following aspects:

1.1.5.1. The defence programme and its components are clearly designed to meet policy objectives

- No

- Partially (please specify)

- Fully and effectively implemented

1.1.5.2. The defence programme includes the programmes and projects considered to have high priority in terms of policy objectives

- No

- Partially (please specify)

- Fully and effectively implemented

1.1.5.3. The defence programme is comprehensive. It covers all defence 
activities and costs, including personnel, operations and maintenance, procurement, utilisation, education and training, etc.

- The defence programme leaves out significant part of the defence activities

- The defence programme incorporates significant part of the defence activities but leaves out certain areas, e.g., acquisition programmes (please specify)

- Yes, it accounts for all activities and costs and constraints all defence resource requirements

1.1.5.4. The defence programme is constrained by resources' forecast

- No attempt is made to constrain the defence programme

- To some extent

- It is within 10 percent of the predicted resource levels

- The defence programme and its components are meticulously tailored to fit the forecast resource framework

1.1.5.5. The defence programme contains alternative options to reflect thoroughly described contingencies

- $\quad$ No

- Partially (please specify)

- Fully and effectively implemented

1.1.5.6. The defence programme effectively incorporates performance indicators

- No

- Partially (please specify)

- Fully and effectively implemented

1.1.5.7. The level of details for the first planning year (or the first two planning years if the country has a two-year budget) of the defence programme is sufficient to allow for its accurate translation into budget plan

- $\quad$ No

- Partially (please specify)

- Fully and effectively implemented

1.2. There is a clear understanding of the risk level associated with the budgeted force structure and defence posture both in short- and mid-term

1.2.1. The country has a methodology to assess risks associated with defence and force planning and sufficient expertise to: 


\subsubsection{Develop scenarios for force implementation}

- There is awareness of the necessity and importance

- A methodology is available

- The country has a methodology adequate to its needs

- Relevant procedures and tools are in place

- The experts involved have the necessary knowledge and experience for effective implementation

1.2.1.2. Assess probability of occurrence of a particular crisis and clearly state assumptions

- There is awareness of the necessity and importance

- A methodology is available

- The country has a methodology adequate to its needs

- Relevant procedures and tools are in place

- The experts involved have the necessary knowledge and experience for effective implementation

\subsubsection{Simulate performance of planned forces}

- There is awareness of the necessity and importance

- A methodology is available

- The country has a methodology adequate to its needs

- Relevant procedures and tools are in place

- The experts involved have the necessary knowledge and experience for effective implementation

\subsubsection{Analyse results and deduct risk}

- There is awareness of the necessity and importance

- A methodology is available

- The country has a methodology adequate to its needs

- Relevant procedures and tools are in place

- The experts involved have the necessary knowledge and experience for effective implementation

1.2.2. The risk assessment is incorporated within the defence/force planning cycle

- No

- Partially (please specify)

- Fully and effectively implemented 
1.3. The budgeting procedure is oriented to reflect precisely policy objectives and programme decisions

- $\quad$ No

- Partially (please specify)

- Fully and effectively implemented

\section{Budgeting procedure and military budget}

2.1. Military budgeting roles and responsibilities within the executive branch and among the braches of power are clearly defined.

2.1.1. Clearly defined roles and responsibilities among the executive branch, the legislature, and the Head of State (the Supreme Commander)

- Unclear

- Clear but with some significant areas of uncertainty

- Very clear

2.1.2. Clearly defined roles and responsibilities among the senior military authorities, the civilian MOD officials and the Ministry of Finance

- Unclear

- Clear but with some significant areas of uncertainty

- Very clear

2.1.3. Clearly defined roles and responsibilities of the public sector and commercial organisations/lobbying groups, in particular commercial organisations owned by the MOD or other governmental agencies

- Unclear

- Clear but with some significant areas of uncertainty

- Very clear

2.2. Clear legal and administrative framework for military budgeting

2.2.1. The legal framework defines clear roles and responsibilities for key aspects of military budgeting

- Unclear

- Partially, with significant gaps

- Comprehensively through complex laws, regulations, and instructions

- Through comprehensive legislation, regulations, and instructions, covered by a budget system law 
2.2.2. The degree of flexibility available to the executives in spending public funds and their discretionary power are clearly described in legal acts

- Public funds can only be spent by law

- The Minister of Defence has effective power over the military budget management

- Any out-of-cycle changes in the defence budget are based on respective changes in the defence programme (authorised by the Minister of Defence or other designated senior resource manager)

- As above and independently audited reports are required

- Individual agencies/defence organisations are held accountable for the funds they collect and/or use

- As above and independently audited reports are required

- Contingency or reserve provisions of the budget law specify clear and stringent conditions for the use of funds

2.3. In a comprehensive manner, the military budget covers all financing ('revenues/ incomes') and spending, including:

\subsubsection{Incomes}

2.3.1.1. Subsidy from the state budget to the Ministry of Defence

- Comprehensively, in gross terms

- Comprehensively, with elaborated purpose

2.3.1.2. Subsidy from the state budget to other organisations performing defence or defence-related activities, i.e., maintenance of wartime reserves

- Not applicable

- No

- Comprehensively, in gross terms

- Comprehensively, with elaborated purpose

2.3.1.3. Funding from other national programmes, i.e., programme for preparation for NATO membership

- Not applicable

- No

- Comprehensively, in gross terms

- Comprehensively, with clearly defined sources and elaborated purpose

2.3.1.4. Funding through international and bi-lateral programmes 
- Not applicable

- $\quad$ No

- Comprehensively, in gross terms

- Comprehensively, with clearly defined sources and elaborated purpose

- As above and there are clear regulations for using reimbursed funds

2.3.1.5. Revenues from sales of excess equipment, infrastructure, etc., i.e., from the release of frequency spectrum used by the military

- Not applicable

- No

- Comprehensively, in gross terms

- Comprehensively, with clearly defined sources and elaborated purpose

2.3.1.6. Revenues from profits of commercial organisations and organisations, providing goods and services to outside organisations, when the MOD owns or has a share in these organisations

- Not applicable

- No

- Comprehensively, in gross terms

- Comprehensively, with clearly defined sources and elaborated purpose

2.3.2. Expenditures

2.3.2.1. Compliance with the UN Instrument for Standardised Reporting of Military Expenditures (Annex B)

- $\quad$ No

- Partial compliance

- A methodology for precise assessment is in place

- The participating experts have the necessary knowledge and adequate experience to estimate accurately the planned expenditures in compliance with the UN Instrument

2.3.2.2. Taxes, i.e., property taxes

- Not applicable (please explain)

- Experts are aware of the necessity

- Rough estimates in gross terms

- A methodology for precise assessment is in place

- As above and the participating experts have the necessary knowledge and 
adequate experience to estimate accurately the planned expenditures

\subsubsection{Social insurance}

- Not applicable (please explain)

- Experts are aware of the necessity

- Rough estimates in gross terms

- A methodology for precise assessment is in place

- As above and the participating experts have the necessary knowledge and adequate experience to estimate accurately the planned expenditures

\subsubsection{Medical insurance}

- Not applicable (please explain)

- Experts are aware of the necessity

- Rough estimates in gross terms

- A methodology for precise assessment is in place

- As above and the participating experts have the necessary knowledge and adequate experience to estimate accurately the planned expenditures

\subsubsection{Retirement costs}

- Not applicable (please explain)

- Experts are aware of the necessity

- Rough estimates in gross terms

- A methodology for precise assessment is in place

- As above and the participating experts have the necessary knowledge and adequate experience to estimate accurately the planned expenditures

2.3.2.6. Costs of social adaptation of prematurely released personnel

- Not applicable

- Experts are aware of the necessity

- Rough estimates in gross terms

- A methodology for precise assessment is in place

- As above and the participating experts have the necessary knowledge and adequate experience to estimate accurately the planned expenditures

2.3.2.7. Costs of utilisation of surplus weapon systems, equipment and infrastructure

- Not applicable (please explain)

- Experts are aware of the necessity 
- Rough estimates in gross terms

- A methodology for precise assessment is in place

- As above and the participating experts have the necessary knowledge and adequate experience to estimate accurately the planned expenditures

2.3.2.8. Costs to cover previous contracts and loan servicing costs

- Not applicable

- Experts are aware of the necessity

- Rough estimates in gross terms

- A methodology for precise assessment is in place

- As above and the participating experts have the necessary knowledge and adequate experience to estimate accurately the planned expenditures

\subsubsection{Contingent liabilities}

- Not applicable

- Experts are aware of the necessity

- Rough estimates in gross terms

- A methodology for precise assessment is in place

- As above and the participating experts have the necessary knowledge and adequate experience to estimate accurately the planned expenditures

2.3.3. Classification of revenues and expenditures in a way that is compatible to GFS/ UN instrument/ $\mathrm{PARP}^{8}$ or another similar international standard (please specify)

- No

- Partially (please, provide details)

- Fully compatible

2.4. Budget information is presented in a way that facilitates policy analysis and promotes accountability. The military budget is represented in the form of:

2.4.1. Appropriations:

- On a gross basis

- With some detail

- With considerable detail

2.4.2. Organisational distribution (assuming the MOD is a 'first level budget holder' and examining its constituent organisations /that are also legal entities/): 
- Not known

- Organisational distribution is known by the executives, but is not included in the budget law

- Among second level budget holders

- Among third level budget holders

\subsubsection{Programmes:}

- Not applicable

- Distribution along programmes is known by the executives, but is not included in the budget law

- Along 'first level' programmes

- Along 'second level' programmes

- On a finer level of detail, clearly describing resources allotted to R\&D, procurement, etc., for each programme and its elements

\section{Budget execution and oversight}

3.1. A comprehensive accounting system provides a reliable basis for assessing payment arrears

- It is of limited capacity and unable to generate reliable data on accounts

- It is reasonably comprehensive and capable of generating reasonable data on accounts

- It is comprehensive and capable of generating data on all stages of the payments and 'incomes'

- It is comprehensive and capable of generating data on all stages of the payments and 'incomes' along budget appropriations, as well as along organisations and programmes

3.2. Personnel, operations and maintenance (O\&M), procurement and $R \& D$ regulations are standardised and accessible to all interested parties:

3.2.1. Employment, release and other personnel policy regulations

3.2.1.1. Employment and pay regulations are:

- Not well defined and allow considerable discretion

- Well defined but some discretion is allowed

- As above, with clear criteria for discretion

- As above and there is competitive recruitment 
3.2.1.2. Employment and pay regulations are observed:

- $\quad$ No

- Only partially

- In full

3.2.2. Military training requirements, e.g., 180 flying hours per crew per year, are standardised and accessible to all interested parties:

3.2.2.1. Training requirements are:

- Not well defined and allow considerable discretion y the military authorities

- Well defined but some discretion is allowed

- As above, with clear criteria for discretion and well documented decisions

3.2.2.2. Training requirements are observed:

- No

- Only partially

- In full

3.2.3. Procurement and other contracting regulations are standardised and accessible to all interested parties

3.2.3.1. There are regulations for open tendering for procurement, $R \& D$ and other contracting services

- None are in place

- Regulations are in place but are unclear or incomplete (please provide additional information)

- The regulations are clear and comprehensive

- As above and the personnel involved is adequately qualified

3.2.3.2. Tendering regulations are observed:

- No

- Only partially

- In full

3.3. In the defence establishment and/or in the executive branch there is a strong capacity for internal audit

3.3.1. Internal audit procedures are clear and subject to effective process review by external auditors

- No 
- Partially (please explain)

- Yes

3.3.2. There is audit capacity in terms of financial compliance and identification of fraud and mismanagement cases

- None

- Weak capacity

- Adequate capacity

- Strong capacity and effective implementation

3.3.3. Audits cover both financial compliance and effectiveness of performance ('value-for-money' analysis). The internal capacity for 'value-for-money' audits can be described as:

- Non existent/ there are no provisions for internal 'value-for-money' audits

- Weak capacity

- Adequate capacity

- Strong capacity and effective implementation

3.4. There is a strong capacity for independent audit, i.e. through a National Audit Office working for the legislature (further down referred to as 'NAO')

3.4.1. Independent audit procedures are clearly established in a law

- No

- Partially (please explain)

- Yes

3.4.2. NAO has audit capacity in terms of financial compliance and identification of fraud/mismanagement cases

- Weak capacity

- Adequate capacity

- Strong capacity and effective implementation

3.4.3. NAO audits cover both financial compliance and effectiveness of performance ('value-for-money' analysis)

- $\quad \mathrm{No} /$ there are no provisions for independent 'value-for-money' audits

- Weak capacity for value-for-money audits

- Adequate capacity

- Strong capacity and effective implementation 
3.5. Independent think-tanks (universities, academic institutes and other nongovernmental organisations) complement 'value for money' audits in particular areas of interest, i.e., force modernisation programmes

- Very limited or non existent capacity

- Limited capacity

- Occasional reports with limited impact

- Notable capacity and track record of successful audits/ reports on performance (please provide examples)

- As above and noticeable impact on decision makers and/or societal attitudes (please provide examples)

3.6. Regular fiscal reporting to the legislature and the public

3.6.1. A mid-year report on budget developments is presented to the legislature. More frequent - at least quarterly — reports are also published

- No requirement to present mid-year report to the legislation

- No requirement to publish governmental financial accounting reports

- Annual publication

- Half-yearly publication

- Quarterly publication

- Monthly publication

3.6.2. Final accounts should be presented to the legislature. Annual reports are audited and submitted to the legislature:

- Not at all or infrequently

- After more than 12 months

- Within twelve months

- Within six months

3.6.3. Results achieved relative to the major programmes are presented to the legislature annually

- No requirement to submit such performance reports

- After more than 12 months, with sketchy performance analysis

- Within twelve months, with sketchy performance analysis

- Within twelve months, with comprehensive and in-depth performance analysis

- Within six months, with comprehensive and in-depth performance analysis 


\section{Level of transparency}

4.1. All aspects of military budgeting (planning, execution and assessment of implementation) are transparent to decision makers and the public. Please identify in Table 1 the actual role of each player in the military budgeting process using the following notation:

Not applicable

No role according to the constitutional arrangement and the legal framework of the country

Has constitutional/legal responsibilities but usually plays a rubberstamp role

Limited influence due to inadequate knowledge and experience

Strong influence, but limited understanding of the complexity and the intricacies of the military budgeting process

Strong influence with full understanding of the military budgeting process and adherence to the principles of democratic governance

Other (please specify)

Table 1: Participation and transparency of decision making

\begin{tabular}{|l|l|l|l|l|l|l|l|}
\hline & a & b & c & d & e & f & g \\
\hline Military planners & & & & & & & \\
\hline $\begin{array}{l}\text { Senior military } \\
\text { leadership, i.e., Defence } \\
\text { Staff }\end{array}$ & & & & & & & \\
\hline $\begin{array}{l}\text { Civilian MOD } \\
\text { administration }\end{array}$ & & & & & & & \\
\hline $\begin{array}{l}\text { Civilian/political } \\
\text { leadership of the MOD }\end{array}$ & & & & & & & \\
\hline Ministry of Finance & & & & & & & \\
\hline $\begin{array}{l}\text { The Government, i.e., } \\
\text { Council of Ministers }\end{array}$ & & & & & & & \\
\hline $\begin{array}{l}\text { The Parliament (as a } \\
\text { whole, including staff }\end{array}$ & & & & & & & \\
\hline $\begin{array}{l}\text { Parliamentarian } \\
\text { committee with }\end{array}$ & & & & & & & \\
\hline
\end{tabular}




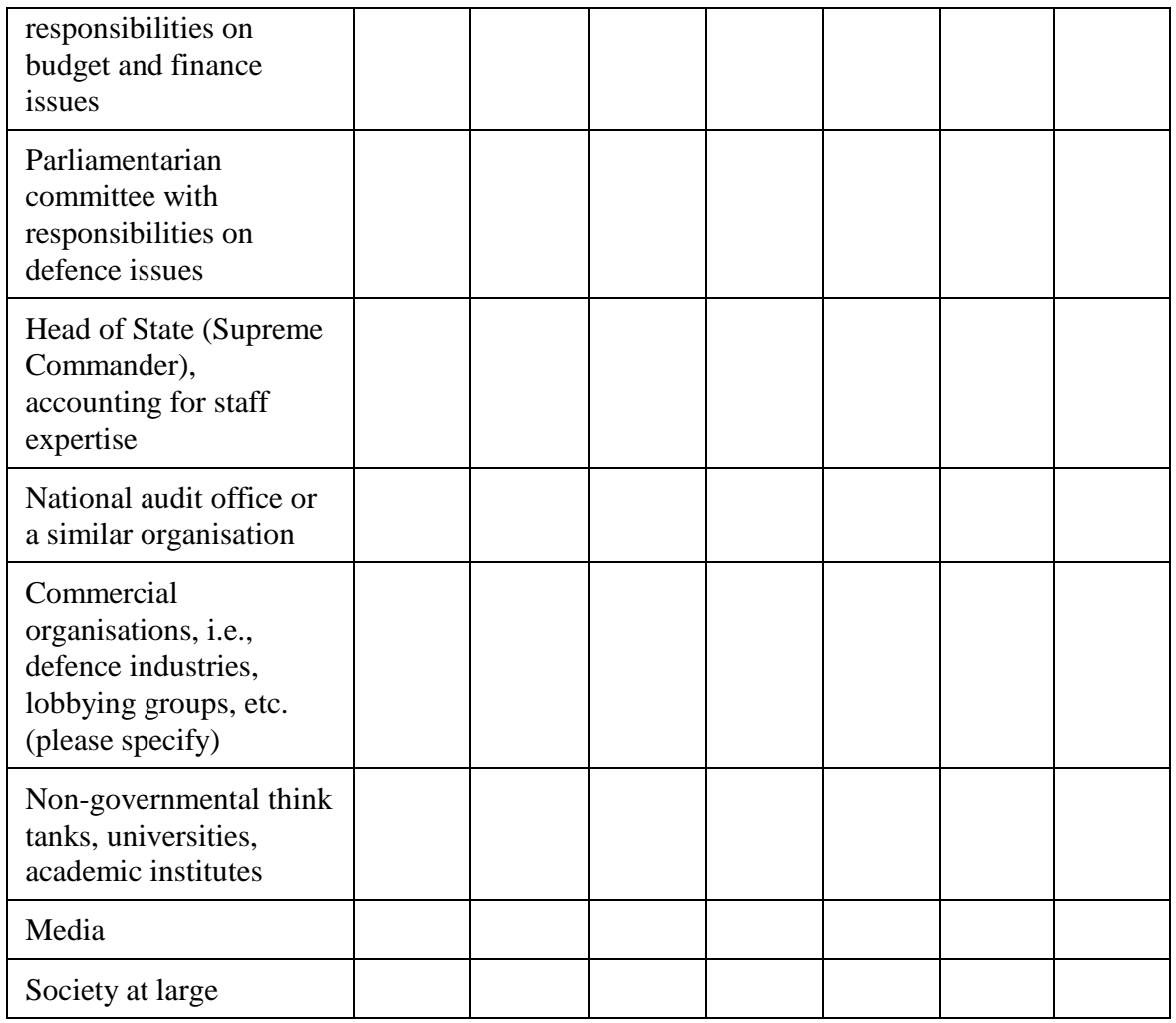

4.2. Publications of military budgets and related information are available to the public

Please identify availability in Table 2 ..

4.2.1. Rules for disclosing military budgets and related information are public
a. No
b. Partially, leaving considerable room for discretion by the executive agencies
c. Partial but clear
d. Clear regulations in significant detail

4.2.2. Reason for publication:

a. Requirements of international organisations

b. Occasional initiative of governmental officials or members of the legislature 
c. Legal obligation of the Government or the respective agency

4.2.3. Level of detail of the publication:

a. Short unclassified (or incomplete for other reasons) version, that hardly allows to form a judgement

b. Partial version, sufficient to form a rough estimate

c. Sufficient to allow rigorous analysis by an informed observer

4.2.4. Media to provide access by the public:

a. Limited printed version in the native language

b. As above plus limited printed version in another commonly used language, i.e., in the English language

c. Freely accessible on-line publication in the native language

d. As above plus freely accessible on-line publication in another commonly used language. i.e., in the English language

4.2.5. Historical information:

a. There is no information on previous years or previous versions of the document

b. Some aggregate information is presented on the budget and the actual or expected outturn of the preceding fiscal year/ short description of previous versions of the document are available

c. As for (b) for the preceding two fiscal years/ full description of previous versions of the document are available

\subsubsection{Budget forecasts}

a. There is no information on years following the budget year

b. Some aggregate information is presented on the budget forecasts for two years following the budget year

c. As for (b) for the five years following the budget year 
Table 2: Availability of military budgeting information

\begin{tabular}{|c|c|c|c|c|c|c|}
\hline & $\begin{array}{l}\text { Non } \\
\text { appli- } \\
\text { cable }\end{array}$ & $\begin{array}{l}\text { Reason } \\
\text { for pub- } \\
\text { lication }\end{array}$ & $\begin{array}{l}\text { Level } \\
\text { of } \\
\text { detail }\end{array}$ & Media & History & $\begin{array}{l}\text { Longer } \\
\text { fore- } \\
\text { casts }\end{array}$ \\
\hline $\begin{array}{l}\text { Major security policy } \\
\text { documents: } \\
\text { - National Security } \\
\text { Strategy }\end{array}$ & & & & & & N/a \\
\hline $\begin{array}{l}\text { - National Security } \\
\text { Concept }\end{array}$ & & & & & & $\mathrm{N} / \mathrm{a}$ \\
\hline $\begin{array}{l}\text { - Other (please } \\
\text { specify) }\end{array}$ & & & & & & N/a \\
\hline $\begin{array}{l}\text { Major defence policy } \\
\text { documents: } \\
\text { - National Military } \\
\text { Strategy }\end{array}$ & & & & & & \\
\hline - Military Doctrine & & & & & & \\
\hline $\begin{array}{l}\text { - Other (please } \\
\text { specify) }\end{array}$ & & & & & & \\
\hline Defence programmes & & & & & & \\
\hline Draft military budgets & & & & & & \\
\hline Military budgets & & & & & & \\
\hline Implementation reports & & & & & & \\
\hline Internal audit reports & & & & & & \\
\hline $\begin{array}{l}\text { Independent- } \\
\text { 'NAO'-audit reports }\end{array}$ & & & & & & \\
\hline $\begin{array}{l}\text { Independent- }-\mathrm{NGO}- \\
\text { audit reports }\end{array}$ & & & & & & \\
\hline $\begin{array}{l}\text { Responds by the } \\
\text { executives to specific } \\
\text { enquiries }\end{array}$ & & & & & & \\
\hline $\begin{array}{l}\text { Other, i.e., transcripts } \\
\text { of parliamentarian } \\
\text { hearings, noteworthy } \\
\text { papers, articles, presen- } \\
\text { tations (please specify } \\
\text { and briefly describe) }\end{array}$ & & & & & & \\
\hline
\end{tabular}


4.3. The country complies with international treaties and agreements, requiring disclosure of military budgeting information, as follows:

a. Not applicable

b. Does not supply regularly the required information

c. The information provided is incomplete

d. The information provided is complete, but often contradicts other sources

e. Complete and accurate information is regularly provided on time

f. Other (please specify)

Please assess the compliance in Table 3.

Table 3: Effectiveness of compliance to international agreements

\begin{tabular}{|l|l|l|l|l|l|l|}
\hline & a & b & c & d & e & f \\
\hline United Nations Instrument & & & & & & \\
\hline $\begin{array}{l}\text { Organization for Security and } \\
\text { Co-operation in Europe (Vienna } \\
\text { documents) }\end{array}$ & & & & & & \\
\hline $\begin{array}{l}\text { Stability Pact for SEE - Budget } \\
\text { Transparency Initiative }\end{array}$ & & & & & & \\
\hline Dayton/Paris Accords & & & & & & \\
\hline $\begin{array}{l}\text { NATO/PfP Planning and Review } \\
\text { Process/ the Interoperability } \\
\text { Survey }\end{array}$ & & & & & & \\
\hline Others (please specify) & & & & & & \\
\hline
\end{tabular}

\section{Assurances of Integrity}

5.1. Rigorous forecasting of the budget/fiscal constraints in a comprehensive and consistent quantitative macroeconomic framework. Forecasts can be best described as:

- Unreliable

- Moderately reliable

- Very reliable 
5.2. The main underlying assumptions in budget planning, i.e., major fiscal risks, exchange rates, uncertain costs, specific expenditure commitments, etc., are clearly documented and properly accounted for

- Assumptions are not clearly stated

- Very few assumptions are properly accounted for

- $\quad$ Some important assumptions are clearly stated (please provide a list)

- All applicable assumptions are clearly documented and properly accounted for

5.3. Underlying assumptions such as macroeconomic forecasts, fiscal forecasts, etc., are assessed by independent experts. External scrutiny of macroeconomic forecasts and models used to generate them is actively encouraged.

- No

- Yes

- Yes and there are formal institutional arrangements to assure external scrutiny

5.4. Defence programmes are properly costed

- Not applicable

- Programmes are costed by the respective programme teams without clear guidance

- Programmes are costed by the respective programme teams following common guidance on major cost factors

- All defence programmes are costed using a comprehensive and consistent set of cost factors

- As above and the cost factors are consistent with the findings of an independent national statistics agency

5.5. Integrity checks are supported by an information system

- No

- Some organisations, participating in the programming and budgeting process, use information systems with limited functionality

- All organisations, participating in the programming and budgeting process, use an information system with limited functionality

- Programming and budgeting are systematically supported by an information system allowing collaborative work

- As above, with integrated tools for automated analysis and decision making 


\section{support}

5.6. The annual budget and the final accounts indicate clearly the accounting basis (e.g., cash or accrual) and standards used in compilation and presentation of budget data

- No statement of the accounting system is provided

- A partial statement is provided

- A full statement is provided indicating any changes in practices as well as current accounting policy

5.7. Alternative programmes/budgets, corresponding to different assumptions, are clearly identified. There is a clear written procedure to transition from one alternative to another and the transition points are clearly documented

- No

- Partially (please explain)

- Yes

5.8. History of both plans and implementation results/assessments is readily available

- No

- Only partial records are available

- Yes, but difficult to obtain and compare

- Yes

5.9. Fiscal reports are internally consistent and reconciled with relevant data from other sources

5.9.1. Accounting reports are reconciled with budget appropriations:

- Ineffectively and not in a timely manner

- Fairly effectively but not in a timely manner

- Effectively and in a timely way

5.9.2. Accounting reports are reconciled with bank accounts:

- Ineffectively and not in a timely manner

- Fairly effectively but not in a timely manner

- Effectively and in a timely way

5.9.3. Auditing of accounting reports is carried out:

- Ineffectively and not in a timely manner

- Fairly effectively but not in a timely manner 
- Effectively and in a timely way

5.9.4. Reconciliation of fiscal and monetary data is:

- Weak

- Moderate

- Rigorous

5.10. A national statistics agency is provided with the institutional independence to verify the quality of budget data

- There is no technically independent national statistics agency

- There is an independent national statistics agency, but it does not play a role in any aspect of military budgeting

- Standards for military budget data integrity and quality are partially adhered to (please explain)

- International standards for budget data integrity and quality are fully adhered to (please identify the standards followed) 


\section{UN Instrument for Standardized International Reporting of Military Expenditures}

Table 4: Instrument for Standardized International Reporting of Military Expenditures

(Actual Outlays, Current Prices)

National Currency and Unit of Measures:

Fiscal Year:

\begin{tabular}{|c|c|c|c|c|c|c|c|c|c|c|c|c|c|c|}
\hline \multirow[t]{2}{*}{ Force Groups---> } & \multirow[t]{2}{*}{$\begin{array}{c}\text { Strategic } \\
\text { Forces }\end{array}$} & \multirow[t]{2}{*}{$\begin{array}{l}\text { Land } \\
\text { Forces }\end{array}$} & \multirow[t]{2}{*}{$\begin{array}{l}\text { Naval } \\
\text { Forces }\end{array}$} & \multirow[t]{2}{*}{$\begin{array}{c}\text { Air } \\
\text { Forces }\end{array}$} & \multirow[t]{2}{*}{$\begin{array}{l}\text { Other } \\
\text { Combat } \\
\text { Forces }\end{array}$} & \multicolumn{2}{|c|}{$\begin{array}{l}\text { Central Support and } \\
\text { Administration } \\
\text { Command }\end{array}$} & \multirow[t]{2}{*}{$\begin{array}{l}\text { Para- } \\
\text { Military } \\
\text { Forces }\end{array}$} & \multicolumn{3}{|c|}{ Military Assistance } & \multirow[t]{2}{*}{$\begin{array}{l}\text { Undistri- } \\
\text { Buted }\end{array}$} & \multirow{2}{*}{$\begin{array}{c}\text { Total } \\
\text { Military } \\
\text { Expen- } \\
\text { ditures }\end{array}$} & \multirow[t]{2}{*}{$\begin{array}{c}\text { Civil } \\
\text { Defence }\end{array}$} \\
\hline & & & & & & Support & Command & & $\begin{array}{c}\text { Home } \\
\text { Territory }\end{array}$ & Abroad & $\begin{array}{l}\text { UN Peace- } \\
\text { Keeping }\end{array}$ & & & \\
\hline Resource Costs & 1 & 2 & 3 & 4 & 5 & 6 & 7 & 8 & 9 & 10 & 11 & 12 & 13 & 14 \\
\hline $\begin{array}{l}\text { 1. Operating } \\
\text { Costs }\end{array}$ & & & & & & & & & & & & & & \\
\hline 1.1. Personnel & & & & & & & & & & & & & & \\
\hline 1.1.1 Conscripts & & & & & & & & & & & & & & \\
\hline $\begin{array}{l}\text { 1.1.2 Other } \\
\text { Military } \\
\text { Personnel } \\
\text { Including } \\
\text { Reserves }\end{array}$ & & & & & & & & & & & & & & \\
\hline $\begin{array}{l}\text { 1.1.3 Civilian } \\
\text { Personnel }\end{array}$ & & & & & & & & & & & & & & \\
\hline
\end{tabular}




\begin{tabular}{|c|c|c|c|c|c|c|c|c|c|c|c|c|c|c|}
\hline \multirow[t]{2}{*}{ Force Groups---> } & \multirow[t]{2}{*}{$\begin{array}{l}\text { Strategic } \\
\text { Forces }\end{array}$} & \multirow[t]{2}{*}{$\begin{array}{l}\text { Land } \\
\text { Forces }\end{array}$} & \multirow[t]{2}{*}{$\begin{array}{l}\text { Naval } \\
\text { Forces }\end{array}$} & \multirow[t]{2}{*}{$\begin{array}{c}\text { Air } \\
\text { Forces }\end{array}$} & \multirow[t]{2}{*}{$\begin{array}{l}\text { Other } \\
\text { Combat } \\
\text { Forces }\end{array}$} & \multicolumn{2}{|c|}{$\begin{array}{c}\text { Central Support and } \\
\text { Administration } \\
\text { Command }\end{array}$} & \multirow[t]{2}{*}{$\begin{array}{l}\text { Para- } \\
\text { Military } \\
\text { Forces }\end{array}$} & \multicolumn{3}{|c|}{ Military Assistance } & \multirow[t]{2}{*}{$\begin{array}{l}\text { Undistri- } \\
\text { Buted }\end{array}$} & \multirow{2}{*}{$\begin{array}{c}\text { Total } \\
\text { Military } \\
\text { Expen- } \\
\text { ditures }\end{array}$} & \multirow[t]{2}{*}{$\begin{array}{c}\text { Civil } \\
\text { Defence }\end{array}$} \\
\hline & & & & & & Support & $\underset{d}{\text { Comman }}$ & & $\begin{array}{c}\text { Home } \\
\text { Territory }\end{array}$ & Abroad & $\begin{array}{l}\text { UN Peace- } \\
\text { Keeping }\end{array}$ & & & \\
\hline Resource Costs & 1 & 2 & 3 & 4 & 5 & 6 & 7 & 8 & 9 & 10 & 11 & 12 & 13 & 14 \\
\hline $\begin{array}{l}1.2 \text { Operations } \\
\text { and Maintenance }\end{array}$ & & & & & & & & & & & & & & \\
\hline $\begin{array}{l}\text { 1.2.1 Materials } \\
\text { for Current Use }\end{array}$ & & & & & & & & & & & & & & \\
\hline $\begin{array}{l}1.2 .2 \\
\text { Maintenance and } \\
\text { Repair }\end{array}$ & & & & & & & & & & & & & & \\
\hline $\begin{array}{l}\text { 1.2.3. Purchased } \\
\text { Services }\end{array}$ & & & & & & & & & & & & & & \\
\hline 1.2.4 Rent Cost & & & & & & & & & & & & & & \\
\hline 1.2.5 Other & & & & & & & & & & & & & & \\
\hline
\end{tabular}




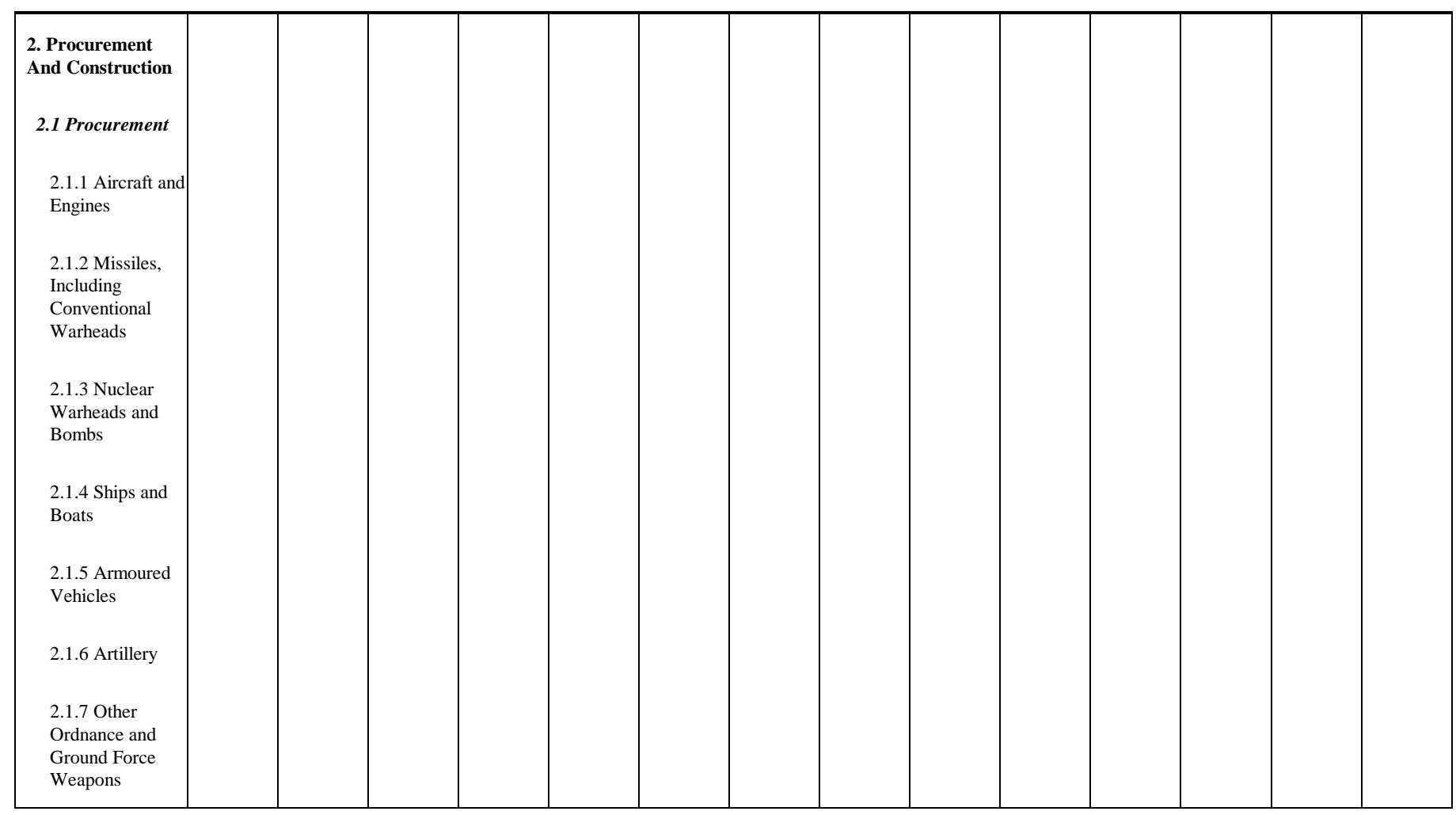




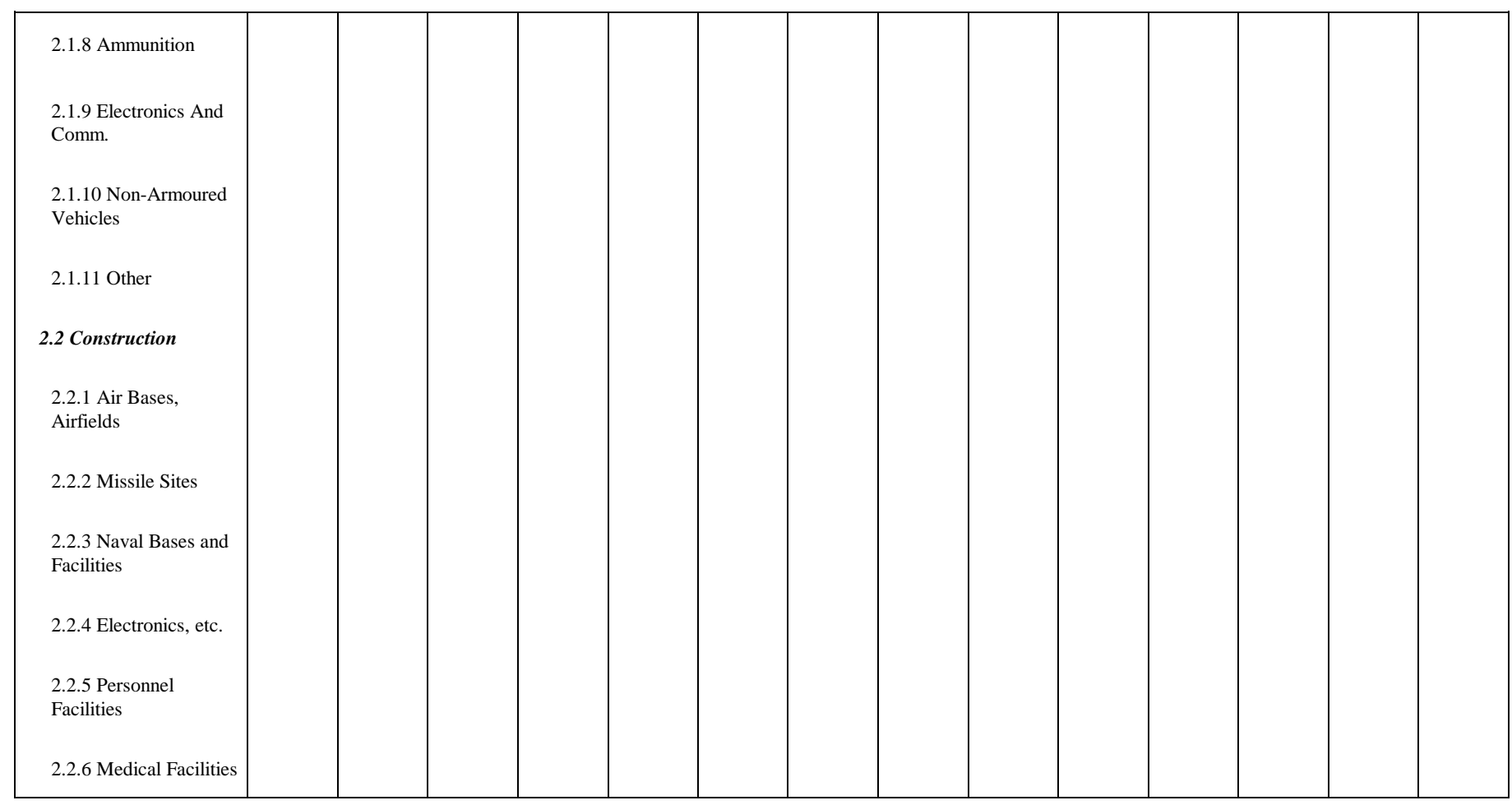




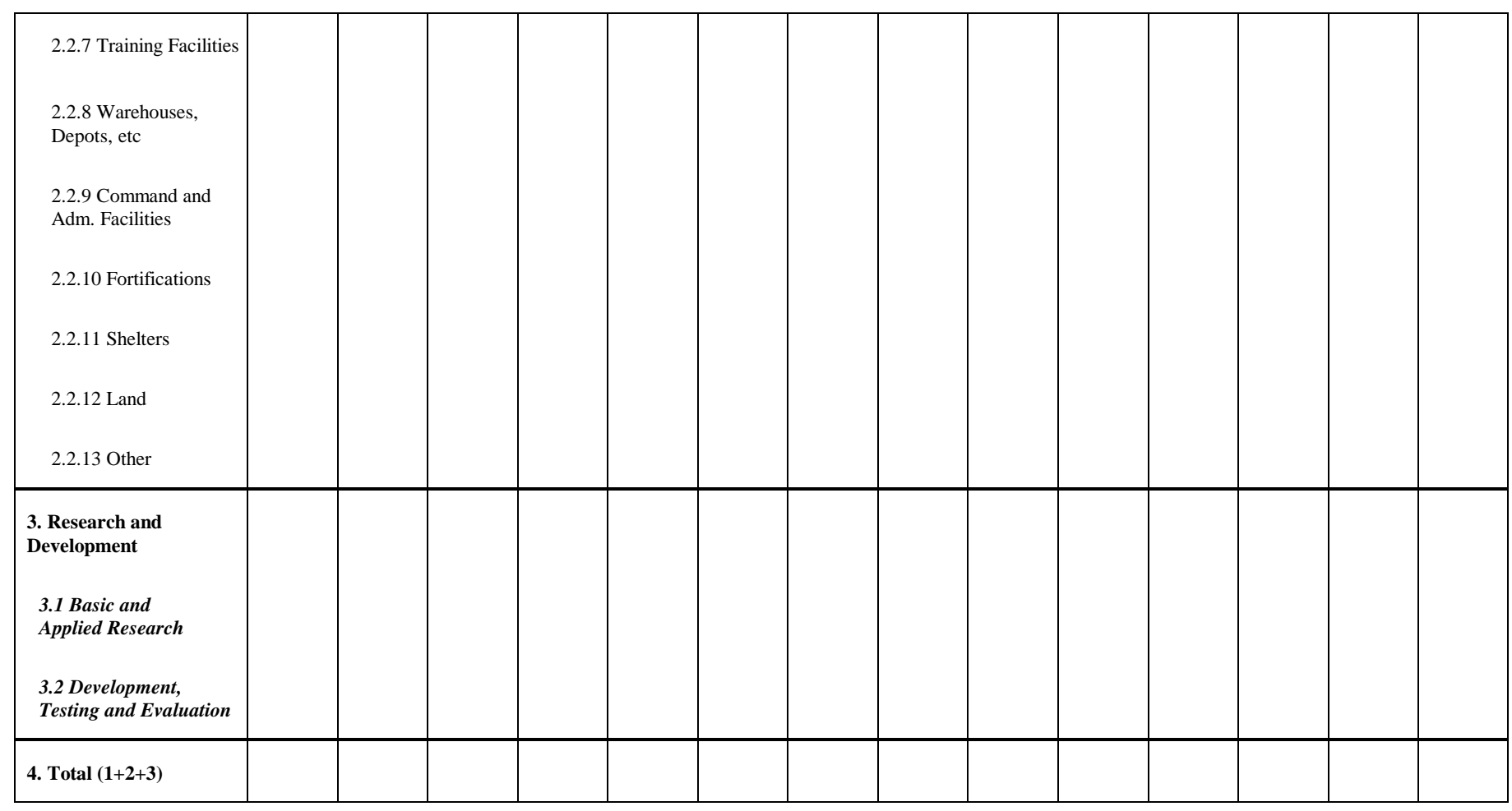




\section{Notes:}

1 For example, the United States use the term Future Years Defense Program (FYDP). A number of South East European countries have also accepted the term programme to denote a resource constraint mid-term plan for development of defence and the armed forces.

Or the first two planning years in case the respective country has a two-year budget. MOD - Ministry of Defence.

GFS - Government Finance Statistics. Details on the UN classification are available online, <http://unstats.un.org/unsd/cr/family2.asp?Cl=218> (24 April 2003).

In Bulgaria, for example, the Prime Minister is legally obliged to present to the legislature "Annual Report on Defence and the Armed Forces" (Law on Defence and the Armed Forces, Article 32a). Although not explicitly required by law, the expectation is that the report will analyse performance and will relate that to actual defence expenditures.

Not as a general rule, but based on a specific decision for classification of a particular piece of information.

7 There are five possible answers to the question for this criterion. The result for country A may be reached processing the answers of four experts; two of them giving the best possible assessment - ' 1 ', and the two others giving ' 0.8 .'

The NATO Planning and Review Process

TODOR TAGAREV is Director Programmes at the Centre for National Security and Defence Research of the Bulgarian Academy of Sciences. He was the first Director of the Defence Planning Directorate of the Bulgarian Ministry of Defence since its establishment in early 1999. From the spring until late 2001, he served as Director for Armaments Policy and National Armaments Director. Among other duties, he led the development of the Bulgarian defence resource management system and coordinated all defence modernisation and R\&D programmes in support of defence reform and NATO integration. He graduated from the Bulgarian Air Force Academy in 1982 and received a PhD degree in systems and control from Zhukovsky Air Force Engineering Academy, Moscow, in 1989. Dr. Tagarev is a 1994 Distinguished Graduate of the US Air Command and Staff College at Maxwell Air Force Base, Ala., and a 1994 Distinguished Young AFCEAn. He is also Director, Research and Publications, of the association "George C. Marshall - Bulgaria." Dr. Tagarev focuses on the integration of information technology with security and defence policy, with over 80 publications on defence planning, information aspects of security, computer modelling and prediction of complex processes - including security and defence related issues. Dr. Tagarev is Editor of Information \& Security: An International Journal <http://www.isn.ethz.ch/ publihouse/InfoSecurity>.E-mail: Tagarev@space.bas.bg. 